\title{
Eosinophilic granulomatosis with polyangiitis (Churg-Strauss syndrome)
}

\author{
DGabriela Venade \\ DCátia Figueiredo ${ }^{1}$ \\ (iD) Catarina Almeida ${ }^{1}$ \\ (iD) Nídia Oliveira ${ }^{1}$ \\ (iD)Luis Costa Matos²
}

1. Interno de Formação Específica em Medicina Interna, Centro Hospitalar Tondela-Viseu 2. Assistente Hospitalar Graduado de Medicina Interna, Centro Hospitalar Tondela-Viseu

\section{SUMMARY}

Churg-Strauss syndrome, Eosinophilic granulomatosis with polyangiitis (EGPA), is a systemic vasculitis that affects small- to medium-sized vessels. It is rare and part of the Anti-neutrophil cytoplasm antibody-associated vasculitis (ANCA) group.

We present a 37-year-old man, with a previous history of asthma, that was sent to the ED due to 2 weeks of productive cough, occasional dyspnea on exertion, fever (one week), asthenia, and anorexia. Upon physical examination, he was subfebrile and tachycardic. He had leukocytosis $\left(17.00 \times 10^{\wedge} \mathrm{g} / \mathrm{L}\right)$ and eosinophilia of $20.0 \%\left(3.4 \times 10^{\wedge} \mathrm{g} / \mathrm{L}\right)$, creatinine level of $1.5 \mathrm{mg} / \mathrm{dL}$, subtle elevation on liver function tests and CRP of $10.82 \mathrm{mg} / \mathrm{dL}$. On Chest X-Ray, there was infiltrate on the right pulmonary base. Due to a strong suspicion of EGPA, he was started on $80 \mathrm{mg}$ of prednisolone from admission. ANCA MPO was positive, with the remaining auto-immune study negative. He underwent Thorax CT (under corticotherapy) without relevant changes, as well as bronchoalveolar lavage, without macroscopic signs of alveolar hemorrhage. Because of active urinary sediment, nephrotic proteinuria $(6.5 \mathrm{~g} / 24 \mathrm{~h})$, and acute renal failure he underwent a renal biopsy, which revealed pauci-immune crescentic glomerulonephritis, with predominantly acute findings (in the context of ANCAMPO Vasculitis - EGPA). After the biopsy, he received three $1 \mathrm{~g}$ methylprednisolone pulses and was started on Cyclophosphamide. He remained asymptomatic and renal function was restored. This case highlights the importance of integrating all findings in one clinical scenario to prevent a more complex disease diagnosis, with a specific treatment, from being missed.

KEYWORDS: Churg-Strauss syndrome. Eosinophils/pathology. Anti-neutrophil cytoplasmic antibody-associated vasculitis.

\section{INTRODUCTION}

Churg-Strauss syndrome, currently called eosinophilic granulomatosis with polyangiitis (EGPA) is a systemic vasculitis that affects small and medium-sized vessels ${ }^{1}$. It is a rare disease belonging to the group of vasculitis associated with antineutrophil cytoplasmic antibody (ANCA) $)^{2}$. According to the American College of Rheumatology, the diagnosis is made when four or more of the following criteria are present: asthma, eosinophilia exceeding 10\%, neuropathy, migratory or transitory pulmonary infiltrates, an anomaly of the paranasal sinuses, and biopsy with areas of accumulation of extravascular eosinophils ${ }^{3}$. It is a rare disease 
and a less common type of vasculitis ${ }^{3}$. We present a case of EGPA that could have gone unnoticed.

\section{CLINICAL CASE}

We present a 37-year-old man, woodworker, with a history of asthma and usually medicated with tiotropium bromide and fluticasone propionate + formoterol fumarate, who attended the ED with a productive cough that had evolved over approximately two months, occasional dyspnea on exertion, fever (with about a week of evolution), asthenia, and anorexia. There were no other symptoms associated. The patient reported a history of recurrent respiratory infections over the previous two months, having carried out several cycles of antibiotic therapy. Upon objective examination, he was subfebrile and presented tachycardia, without any other changes in the scenario. An analysis showed leukocytosis with 20.0\% eosinophilia, renal dysfunction, discrete alteration of liver function, and CRP of $10.82 \mathrm{mg} / \mathrm{dL}$ (Table 1). A chest $\mathrm{x}$-ray showed infiltrate in the right lung base (Figure 1). Abdominal and renal ultrasound showed kidneys of normal dimensions and increased echogenicity with reduced parenchymal-sinusal differentiation, without any other changes in the scenario. The patient was admitted to hospital for continuity of the diagnostic study. Due to a high suspicion of EGPA, prednisolone $80 \mathrm{mg}$ was administered since admission. Microbiological studies, as well as serologies, came back negative

\begin{tabular}{|c|c|c|c|c|c|}
\hline \multicolumn{3}{|c|}{ Analytical investigation at the ED } & \multicolumn{3}{|c|}{ Etiologic analytical study upon admission } \\
\hline Test & Results & Reference Values & Test & Results & Reference Values \\
\hline Leukocytes & $17.00 \times 10^{9} / \mathrm{L}$ & $4.50-11.50$ & Rheumatoid Factor & $17.3 \mathrm{UI} / \mathrm{mL}$ & $<20.0$ \\
\hline Neutrophils & $67.5 \%$ & & ANA (IFI) & Negative & \\
\hline Eosinophils & $20.0 \%$ & & Ab. Anti-DNA & Negative & \\
\hline Hemoglobin & $12.8 \mathrm{~g} / \mathrm{dL}$ & $14.0-18.0$ & Ab. Anti dsDNA & $1.0 \mathrm{U} / \mathrm{mL}$ & $0.0-15.0$ \\
\hline Platelets & $336.0 \times 10^{9} / \mathrm{L}$ & $150.0-450.0$ & ENA screen & Negative & \\
\hline Creatinine clearance & $1.5 \mathrm{mg} / \mathrm{dL}$ & $0.6-1.3$ & $\begin{array}{l}\text { Anti-MPO antibodies } \\
\text { Anti-PR3 antibodies }\end{array}$ & $\begin{array}{l}393.00 \mathrm{U} / \mathrm{mL} \\
0.50 \mathrm{U} / \mathrm{mL}\end{array}$ & $\begin{array}{l}0.00-10.00 \\
0.00-10.00\end{array}$ \\
\hline FA & $116.0 \mathrm{UI} / \mathrm{L}$ & $25-100$ & HIV 1+2 - Ag. + Total Ab. & 0.15 Index & Non-Reactive \\
\hline GGT & 167.0UI/L & $7.0-49.0$ & $\begin{array}{l}\text { Ag. HBs } \\
\text { Ab. HBs } \\
\text { AB. HBc } \\
\text { Ab. Total HCV }\end{array}$ & $\begin{array}{l}0.12 \text { Index } \\
<3.1 \mathrm{mUI} / \mathrm{mL} \\
0.12 \text { Index } \\
0.09 \text { Index }\end{array}$ & $\begin{array}{l}\text { Non-Reactive } \\
\text { Non-Reactive } \\
\text { Non-Reactive } \\
\text { Non-Reactive }\end{array}$ \\
\hline ALT & 110UI/L & $4-43$ & Vit B12 & 497.0pg/mL & 179.0-1130.0 \\
\hline AST & 60UI/L & $4-43$ & Tryptase & 8.0 $\mu \mathrm{g} / \mathrm{L}$ & $<11.4$ \\
\hline CRP & $10.82 \mathrm{mg} / \mathrm{dL}$ & $<0.50$ & Aspergillus fumigatus (m3) & $0.30 \mathrm{KUA} / \mathrm{L}$ & \\
\hline
\end{tabular}
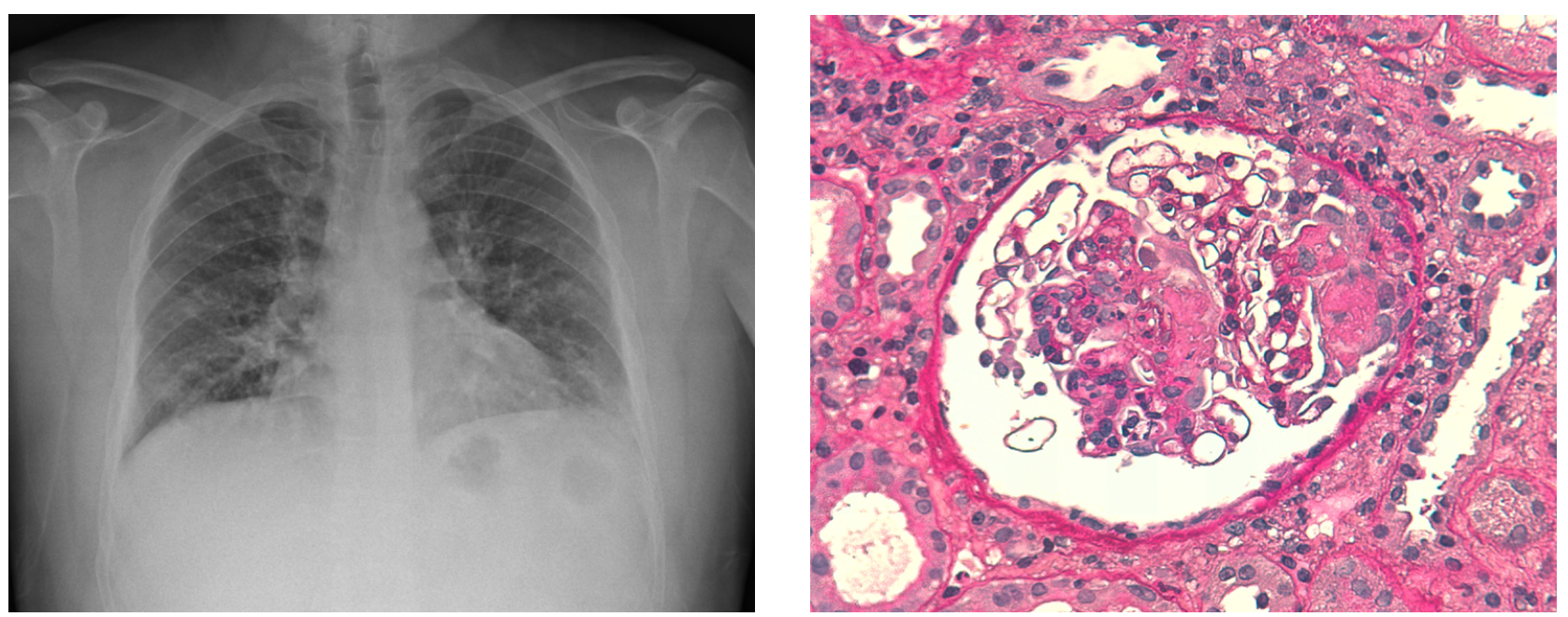
(Table 1). ANCA MPO was positive, and the remainder study of autoimmunity was negative. Chest CT was performed (already under corticotherapy) without changes in the scenario, as well as bronchoalveolar lavage without macroscopic signs of alveolar hemorrhage. Due to renal involvement with active urinary sediment, proteinuria in the nephrotic range (6.56 $\mathrm{g} / 24 \mathrm{~h}$ ), and acute kidney injury, a renal biopsy was performed, which showed pauci-immune crescentic glomerulonephritis, with predominantly acute findings (in the context of ANCA Vasculitis - MPO - Eosinophilic Granulomatosis with Polyangiitis) (Figure 2).

After the biopsy, three pulses of $1 \mathrm{~g}$ of methylprednisolone were administered. Given the severe renal involvement, cyclophosphamide was initiated with prophylaxis for associated hemorrhagic cystitis, pneumocystosis, and oral candidiasis. The patient showed improvement in the respiratory condition, becoming asymptomatic, as well as of renal function, with $\mathrm{Cr}$ of $1.1 \mathrm{mg} / \mathrm{dL}$ at the date of discharge. Follow-up was conducted on external consultations.

\section{DISCUSSION}

EGPA is a rare condition that mainly affects individuals aged between 7 and 74 years, with an average diagnosis age between 38 and 54 years and no gender predominance ${ }^{4}$. Our patient fits into the average age for diagnosis.

The etiopathology of the disease remains unknown, but some environmental factors have been mentioned as potential triggers, including allergens, infections, vaccines, and medication ${ }^{2.5}$.

It is known that the EGPA develops in three sequential stages: the prodromal or allergic stage, the eosinophilic stage, and the vasculitis stage. The first is distinguished by the onset of asthma, allergic rhinitis, and sinusitis, and asthma is the main manifestation of this stage and present in most patients. In the second stage, patients develop the main pathological findings, with increased peripheral eosinophil count and their infiltration into various organs, particularly the lungs, heart, and gastrointestinal tract, and the pulmonary parenchyma is involved in two-thirds of patients with this diagnosis. Migratory infiltrates on chest x-ray are very characteristic of this disease. Finally, there is the vasculitis stage, in which the patient develops the consequences of necrotizing vasculitis, such as, purpura and peripheral neuropathy, which are usually accompanied by constitutional symptoms such as fever, general malaise, and weight loss ${ }^{2.6}$. The main histopathological findings are extravascular granulomas, vasculitis of small and medium-sized vessels, and eosinophilic infiltrates ${ }^{2}$. Our patient presented at the ED probably in the eosinophilic stage, progressing to the vasculitis stage, given the presence of peripheral eosinophilia, with a likely early pulmonary involvement and severe renal involvement, with acute findings of pauci-immune crescentic glomerulonephritis in renal biopsy. When a chest CT was performed, the patient was already under corticotherapy, which could justify the absence of alterations on this exam.

The differential diagnoses for EGPA are essentially eosinophilic diseases and other types of vasculitis ${ }^{2,6,7}$.

When there is a suspicion of this disease, a biopsy is encouraged. A biopsy demonstrating vasculitis of small or medium-sized vessels, for example, fibrinoid necrosis, leukocytoclastic, or pauci-immune crescentic glomerulonephritis, along with the clinical context of asthma and eosinophilia, safely supports the diagnosis $^{7}$. In 1990, the American College of Rheumatology defined six criteria for the diagnosis of EGPA. Since then, the most commonly used have been: asthma, eosinophilia $>10 \%$, neuropathy, migratory or transitory pulmonary infiltrates, an anomaly of the paranasal sinuses, and biopsy with areas of accumulation of extravascular eosinophils. For the diagnosis to be established, four or more of these criteria must be present ${ }^{6}$. In this case, there are four criteria present, one of them being the biopsy, which allowed us to confirm the diagnosis.

The treatment is based on a Five-Factor Score (FFS), with one point assigned to each one. They are gastrointestinal involvement, involvement of the central nervous system, cardiac involvement, proteinuria $>1 \mathrm{~g} / 24 \mathrm{~h}$, and serum creatinine above $1.58 \mathrm{mg} / \mathrm{dL}$. If the patient has a FFS $=0$, this means a better prognosis, and therapy with glucocorticoids alone is the treatment indicated. If the patient has FFS $>1$, given the worst prognosis associated with this score, the indication is for treatment with glucocorticoids associated with immunosuppressive drugs, namely cyclophosphamide $^{2,6,7}$. Our patient was under corticotherapy from admission due to the high clinical suspicion of EGPA and the observation of renal involvement; therefore, with FFS $>1$, cyclophosphamide pulses were started. Although Cr was $1.5 \mathrm{mg} / \mathrm{dL}$ ate admission, it was established, upon the consultation of records, that this was a chronic renal disease, so renal involvement was not assumed $a b$ initio. 


\section{CONCLUSION}

This case aims to draw attention to the diagnosis of a rare condition that requires attention and clinical suspicion, as well as the integration of all findings into one clinical scenario, since, in this case, right pneumonia with acute kidney injury could be easily assumed, thus ignoring a more severe diagnosis with specific treatment.

\section{RESUMO}

A vasculite de Churg-Strauss, granulomatose eosinofilica com poliangeíte (EGPA), é uma vasculite sistêmica que afeta vasos de pequeno e médio calibre. É rara e pertence ao grupo de vasculites associadas a anticorpos anticitoplasma de neutróflos (Anca).

Apresenta-se um homem de 37 anos, com antecedentes de asma, que recorre ao SU por tosse produtiva com dois meses de evolução, dispneia ocasional em esforço, febre (uma semana de evolução), astenia e anorexia. Ao exame objetivo apresentava-se subfebril e taquicárdico. Analiticamente com leucocitose (17,00 ×10^9/L) e eosinofilia de 20,0\% (3,4 X10^9/L), creatinina de 1,5 mg/dL, discreta alteração das provas de função hepática e PCR de 10,82 mg/dL. Na radiografia de tórax objetivava-se infiltrado na base pulmonar direita. Por elevada suspeita de EGPA, iniciou prednisolona $80 \mathrm{mg}$ desde a admissão. Anca MPO+, com restante estudo de autoimunidade negativo. Realizou TC tórax (sob corticoterapia) sem alterações de relevo, bem como lavado bronco-alveolar, sem sinais macroscópicos de hemorragia alveolar. Por sedimento urinário ativo, proteinúria na faixa nefrótica (6,56 g/24h) e lesão renal aguda, realizou biópsia renal que revelou glomerulonefrite crescêntica pauci-imune, com achados predominantemente agudos (no contexto de Vasculite AncaMPO - EGPA). Após biópsia, realizou três pulsos de $1 \mathrm{~g}$ de metilprednisolona e iniciou ainda ciclofosfamida. Ficou assintomático e com recuperação da função renal.

Este caso realça a importância de integração de todos os achados num só cenário a fim de evitar que escape o diagnóstico de uma doença mais complexa e com um tratamento específico.

PALAVRAS-CHAVE: Síndrome de Churg-Strauss. Eosinófilos/patologia. Vasculite associada a anticorpo anticitoplasma de neutrófilos.

\section{REFERENCES}

1. Jennette |C, Falk RJ, Bacon PA, Basu N, Cid MC, Ferrario F, et al. 2012 revised International Chapel Hill Consensus Conference Nomenclature of Vasculitides. Arthritis Rheum. 2013;65(1):1-11.

2. Gioffredi A, Maritati F, Oliva E, Buzio C. Eosionophilic granulomatosis with polyangiitis: an overview. Front Immunol. 2014;5:549.

3. Mouthon L, Dunogue B, Guillevin L. Diagnosis and classification of eosinophilic granulomatosis with polyangitis (formerly named Churg-Strauss syndrome). J Autoimmun. 2014;48-49:99-103.

4. Sinico RA, Bottero P. Churg-Strauss angiitis. Best Pract Res Clin Rheumatol.
2009;23(3):355-66.

5. Ramentol-Sintas M, Martínez-Valle F, Solans-Laqué R. Churg-Strauss syndrome: an evolving paradigm. Autoimmun Rev. 2012;12(2):235-40

6. Greco A, Rizzo MI, De Virgilio A, Gallo A, Fusconi M, Ruoppolo G, et al. Churg-Strauss syndrome. Autoimmun Rev. 2015;14(4):341-8.

7. Groh M, Pagnoux C, Baldini C, Bel E, Bottero P, Cottin V, et al. Eosinophilic granulomatosis with polyangiitis (Churg-Strauss) (EGPA) Consensus Task Force recommendations for evaluation and management. Eur J Intern Med. 2015;26(7):545-53. 